\title{
ASSESSMENT OF THE EFFECTIVENESS OF ACTIVE SIGNAGE AT PEDESTRIAN CROSSINGS
}

\author{
P. OLSZEWSKI ${ }^{1}$, W. CZAJEWSKI ${ }^{2}$, P. DĄBKOWSKI ${ }^{3}$, \\ C. KRAŚKIEWICZ ${ }^{4}$, P.SZAGALA ${ }^{5}$
}

\begin{abstract}
The paper presents findings from research project Mobis which is aimed at developing a method of assessing safety of unsignalised pedestrian road crossings using video image analysis. Pedestrian and vehicle traffic has been recorded at selected zebra crossing sites in Warsaw and Wrocław, before and after installation of active signage systems SignFlash and Levelite. Speeds of approaching vehicles were measured and drivers' behaviour was classified using video analysis.

The paper presents a comparison of effectiveness of systems such as SignFlash and Levelite based on changes in the mean and standard deviation of vehicle spot speeds as well as changes in speed profiles of vehicles approaching the crossings.

Results indicate that both SignFlash and Levelite active signage reduce mean vehicle approach speeds and have a positive impact on drivers' behaviour.
\end{abstract}

Keywords: Pedestrian safety, pedestrian crossing, speed survey, SignFlash, Levelite

\footnotetext{
${ }^{1}$ Warsaw University of Technology, Faculty of Civil Engineering, al. Armii Ludowej 16, 00-637 Warsaw, Poland, e-mail: p.olszewski@il.pw.edu.pl

${ }^{2}$ Warsaw University of Technology, Faculty of Electrical Engineering, Pl. Politechniki 1, 00-661 Warsaw, Poland, e-mail: w.czajewski@isep.pw.edu.pl

${ }^{3}$ Warsaw University of Technology, Faculty of Civil Engineering, al. Armii Ludowej 16, 00-637 Warsaw, Poland, e-mail: p.dabkowski@il.pw.edu.pl

${ }^{4}$ Warsaw University of Technology, Faculty of Civil Engineering, al. Armii Ludowej 16, 00-637 Warsaw, Poland, e-mail: c.kraskiewicz@il.pw.edu.pl

${ }^{5}$ Warsaw University of Technology, Faculty of Civil Engineering, al. Armii Ludowej 16, 00-637 Warsaw, Poland, e-mail: p.szagala@il.pw.edu.pl
} 


\section{INTRODUCTION}

Poland has the second highest pedestrian fatality rate in the European Union: 30 annual deaths per million inhabitants. In 2014 on Polish roads 1116 pedestrians were killed (35\% of all traffic fatalities) and 8398 were injured (20\%) [1]. In the years 2008-2013 about $13 \%$ of pedestrian victims were killed and $26 \%$ injured at unsignalised zebra crossings where pedestrians should theoretically be safe.

Although the pedestrian safety situation is slowly improving, it is clear that more measures should be taken to decrease the numbers of accident victims at pedestrian crossings.

According to Retting et al. [5] measures to improve safety of pedestrians crossing roads include: separation of pedestrians and vehicles by time or space, managing vehicle speeds and increasing pedestrian visibility.

Active signage systems which involve flashing lights warning drivers about the crossing location and pedestrian presence help in several of the above aspects - they increase pedestrian visibility and induce drivers to lower their speeds. According to American [6] [7] and Israeli [8] field studies, active signage systems are quite effective in decreasing vehicle speeds and improving drivers' behaviour in terms of willingness to give way to pedestrians.

The aim of project Mobis [2] [3] is to develop and test a method of assessing safety of pedestrian road crossings using automatic video image analysis. During the project, field tests are conducted at zebra crossings with different safety measures. Pedestrian and vehicle traffic is recorded with at least two digital cameras for each traffic direction.

Statistical analysis of conflict and dangerous situations is conducted in order to develop surrogate safety measures, appropriate for pedestrian crossings. It is hoped that safety assessments can then be made based on relatively short observation periods and will provide an objective evaluation of measures used to improve pedestrian safety.

The paper presents some findings from the project, based on field tests conducted in Warsaw and Wrocław. Pedestrian and vehicle traffic was recorded at selected sites for at least three weeks before and after installation of safety measures which included active signage systems: SignFlash and Levelite. In case of Warsaw site recording was done also for a period of about one month after removal of the safety measure. 


\section{TEST SITES}

\subsection{SITES SELECTED}

The observations were conducted at two pedestrian zebra crossings in Warsaw and two in Wrocław. The test sites were selected based on high pedestrian traffic volume, considerable number of pedestrian-vehicle accidents in the past and availability of facilities for equipment installation in the vicinity of the crossing. Fig. 1 shows the layout of the zebra crossing sites. In Warsaw, the crossing selected for data collection was located at the intersection of Wrocławska and Blatona streets, where 6 pedestrian-vehicle accidents were reported between 2006 and 2011. Wrocławska Street is a 4-lane undivided road with a refuge island in the middle of the zebra crossing. The two half-crossings were designated by traffic direction as POW (Fig. 1a) and RAD. All lanes were monitored in the direction of incoming traffic. Traffic survey showed a pedestrian crossing volume of 150-420 persons per hour in both directions. The second test site was selected in Wrocław at the intersection of Mickiewicza and Godebskiego streets. According to the Police records, there were 5 pedestrian-vehicle accidents there from 2006 to 2011. This test site is a two-lane undivided road with two zebra crossings in the area of the intersection. The two crossings were designated by traffic direction as CEN and SWO. Each pedestrian crossing was fully covered by the vision system, but due to technical reasons the vehicle traffic was monitored from only one direction for each zebra.

a) Warsaw, POW direction

b) Wrocław, both directions
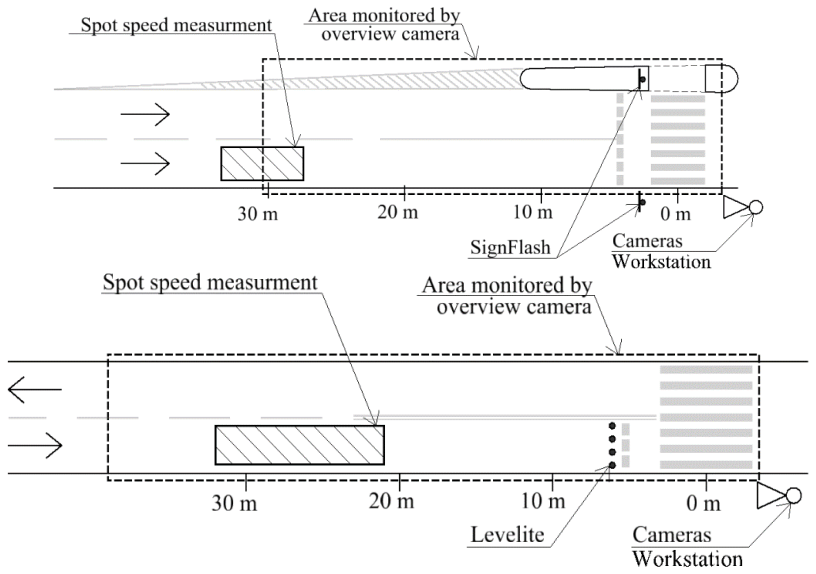

Fig. 1. Layout of the two test sites in Warsaw (a) and Wrocław (b) 


\subsection{EQUIPMENT SETUP}

For each crossing a dedicated video recording and processing system was installed and recordings were made for a period of two to three months. Finally, a batch of approximately four weeks of data from each crossing was selected for further processing. The vision recording system, installed at each crossing and in each direction, consisted of the following components:

- a digital overview camera covering the area of the pedestrian crossing and its approach road section of 30-40 m;

- one digital directional camera per lane, covering road section approximately $3.5 \mathrm{~m}$ wide and $6 \mathrm{~m}$ long, located within the approach area monitored by the overview camera;

- a workstation used for recording and preliminary analysis of the digital video signal taken from the cameras and enabling remote control and diagnostics.

\subsection{SAFETY IMPROVEMENT MEASURES}

Several safety improvement measures were tested during the project. At one approach at the Warsaw test site (POW direction) the SignFlash system (SF) was installed which is an example of an active signage system. It is equipped with pedestrian movement sensors which activate yellow flashing lights when pedestrians are crossing the road [4].

Traffic was monitored before and after the installation. Recordings from 23 days of favourable weather conditions (overcast, no shadows or rain) were selected for in depth analysis - 12 days without the SF system and 11 days with the SF.

Another type of active signage - Levelite (LL) - was tested in Wrocław.

It consists of flashing lights embedded in the pavement which either flash continuously or only when activated by pedestrian detectors. The two modes of operation were tested at two Wrockaw test sites: continuous flashing in the CEN direction and pedestrian activation in the SWO direction. Overview camera recordings from 27 days were preselected for further processing, but up until the writing of this paper, only one day of data without the LL system (01.10.2014) and one with the LL (06.11.2014) were available for comparison. 


\section{SPOT SPEED ANALYSIS}

\subsection{SPEED MEASUREMENT}

The directional cameras were used for speed measurements of vehicles approaching the pedestrian crossing. They determined vehicles' speeds using a frame-by-frame method, i.e. measuring the distance travelled between subsequent frames of the recorded video. The cameras went through a calibration process in order to determine the three parameters required to assess vehicle speeds two camera tilt angles (external parameters) and a scaling factor (an internal parameter dependent on focal length). The measurements were taken between 17 and $32 \mathrm{~m}$ upstream of the crossing. The speeds measured at such a distance do not allow for precise assessment of the drivers' responses to the events within the area of the crossing (e.g. people waiting and crossing), but they allow for analysis of speed variability and thus for assessing the impact on speed of the safety measures introduced. The spot speeds were examined at three sites: Warsaw direction POW (lane L1 and L2), Wrocław direction CEN and Wrocław direction SWO. Table 1 shows the data aggregated in 1-hour intervals: mean hourly traffic volumes, mean speeds and their standard deviations for the three sites.

Table 1. Vehicle spot speed analysis for the three sites

\begin{tabular}{|c|c|r|r|r|r|}
\hline \multirow{2}{*}{ Site } & Safety measure & $\begin{array}{c}\text { Sample size } \\
{[\text { hours }]}\end{array}$ & $\begin{array}{c}\text { Mean traffic } \\
\text { volume } \\
{[\mathrm{veh} / \mathrm{h}]}\end{array}$ & $\begin{array}{c}\text { Mean speed } \\
{[\mathrm{km} / \mathrm{h}]}\end{array}$ & Speed SD $[\mathrm{km} / \mathrm{h}]$ \\
\hline \multirow{2}{*}{ Warsaw POW L1 } & - & 648 & 110 & 45.1 & 3.82 \\
\cline { 2 - 6 } & + & 535 & 101 & 43.9 & 4.13 \\
\hline \multirow{2}{*}{ Warsaw POW L2 } & - & 648 & 92 & 50.5 & 6.05 \\
\cline { 2 - 6 } & + & 535 & 84 & 49.5 & 6.27 \\
\hline \multirow{2}{*}{ Wrocław CEN } & - & 1782 & 307 & 48.8 & 9.63 \\
\cline { 2 - 6 } & + & 1851 & 341 & 42.7 & 9.81 \\
\hline \multirow{2}{*}{ Wrocław SWO } & - & 864 & 303 & 43.4 & 7.36 \\
\cline { 2 - 6 } & + & & & & 8.90 \\
\hline
\end{tabular}

The results show that for all the sites the average speeds calculated for "with safety measure" periods are lower than those calculated for "without safety measure" periods. Regarding standard deviations of speeds it is worth noting that the values derived for Wrocław site are higher than 
for the Warsaw site. This could be explained by different cross-sections (4 lane road divided with a refuge island in Warsaw and two-way two-lane road in Wrocław).

It should be noted that the speeds were analysed for all vehicles, not only those encountering pedestrians. It is expected that differences in speeds calculated only for vehicles encountering pedestrians will be bigger than those presented in the table. Such an analysis will be done in the next stage of the project. Furthermore, the analysis does not take into account an effect of traffic volume on speeds - this problem is analysed in the next section.

\subsection{REGRESSION ANALYSIS}

In order to separate the effects of safety measures (SM) on traffic speed from the effects of changes in traffic volume, a regression analysis of mean hourly traffic spot speed as a function of hourly traffic volume and safety measure presence was performed for the three sites. The equation used had the following general form:

$$
\text { Speed }=b_{0}+b_{1} \cdot V o l+b_{2} \cdot S M+b_{3} \cdot A S M+\varepsilon
$$

where:

Vol - hourly vehicular traffic volume approaching the crossing (veh/h), $S M$ - dummy variable indicating the period: equal to 1 when SM was present and 0 when SM was not present, $A S M$ - dummy variable for the period after the SM was removed (Warsaw only), $b_{0}, b_{1}, \ldots$-regression coefficients, $\varepsilon$ - random error component.

The results are presented in Tables 2 and 3. Both the traffic volume and the safety measure presence were statistically significant at $1 \%$ level $(\mathrm{P}$-value $<0.01)$. Figure 2 shows a graphical presentation of the results for the Wrocław CEN site.

Table 2. Regression analysis results, Warsaw POW site

\begin{tabular}{|c|c|c|c|c|c|c|}
\hline \multirow{2}{*}{ Variable } & \multicolumn{3}{|c|}{ Lane 1 } & \multicolumn{3}{c|}{ Lane 2 } \\
\cline { 2 - 7 } & Coeff. & t Stat & P-value & Coeff. & t Stat & P-value \\
\hline Constant & 49.989 & 222.5 & 0.000 & 58.106 & 203.3 & 0.000 \\
\hline Vol & -0.037 & -33.4 & 0.000 & -0.072 & -45.7 & 0.000 \\
\hline SM (SignFlash) & -2.367 & -10.4 & 0.000 & -2.553 & -8.6 & 0.000 \\
\hline After_SM & -1.262 & -5.4 & 0.000 & -1.567 & -5.1 & 0.000 \\
\hline $\mathrm{R}^{2}$ & & 0.506 & & 0.646 & \\
\hline
\end{tabular}


Table 3. Regression analysis results, Wrocław sites

\begin{tabular}{|c|c|c|c|c|c|c|}
\hline \multirow{2}{*}{ Variable } & \multicolumn{3}{|c|}{ CEN } & \multicolumn{3}{c|}{ SWO } \\
\cline { 2 - 7 } & Coeff. & $\mathrm{t}$ Stat & P-value & Coeff. & t Stat & P-value \\
\hline Constant & 59.842 & 291.5 & 0.000 & 54.945 & 322.1 & 0.000 \\
\hline Vol & -0.035 & -68.3 & 0.000 & -0.032 & -70.7 & 0.000 \\
\hline SM (Levelite) & -5.360 & -21.6 & 0.000 & -1.939 & -10.3 & 0.000 \\
\hline $\mathrm{R}^{2}$ & & 0.701 & & 0.673 \\
\hline
\end{tabular}

The results show that there is a significant drop in the mean speeds with safety measures compared to those without, for all the sites and entire range of traffic volumes. The biggest drop $(5.36 \mathrm{~km} / \mathrm{h})$ was achieved at the Wrocław CEN site, i.e. the site equipped with LL system working continuously. It is three times more than for Wrocław SWO site (pedestrian activated LL system). This could be explained by the fact, that at the first site all vehicles were affected by the system which resulted in lower mean speeds than in case of the site where the signal was displayed only to a portion of the vehicles.

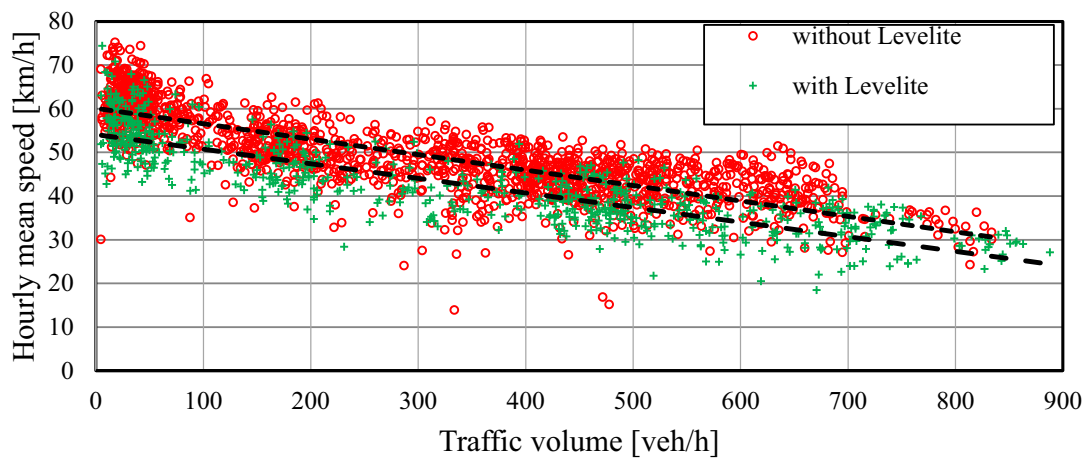

Fig. 2. Regression analysis for the Wrocław CEN site

The speed reduction for Warsaw site (pedestrian activated SF system) was statistically significant but moderate (2.37 $-2.55 \mathrm{~km} / \mathrm{h}$ depending on the lane), still it was higher than for the comparable Wrocław site $(1.94 \mathrm{~km} / \mathrm{h})$. It seems that it is due to better visibility of the SF lights. Nevertheless, it should be born in mind that the two sites are of different cross-sections, which could affect the results. It is interesting that over $50 \%$ of the speed reduction effect in Warsaw $(1.26-1.57 \mathrm{~km} / \mathrm{h})$ was still observed during one month after removal of the SF system. 


\section{SPEED PROFILE ANALYSIS}

\subsection{ENCOUNTER CLASSIFICATION}

Video material recorded at the test sites by the overview cameras was the basis for a more detailed examination of vehicle-pedestrian encounters. These are defined as situations when both vehicles and pedestrians were simultaneously present in the area being monitored. All the encounters were classified into the following categories (see Fig. 3):

- Situation A1 - vehicle passes directly in front of a pedestrian who is on the zebra crossing,

- Situation A2 - vehicle passes directly in front of a pedestrian who is on the sidewalk,

- Situation B - vehicle passes immediately behind a pedestrian who is on the zebra crossing or on the sidewalk,

- Situation C - vehicle clearly slows down or stops on the approach to the pedestrian crossing.

Situation $\mathrm{C}$ represents drivers giving way to pedestrians. The total number of registered events and their distribution are shown in Table 4.

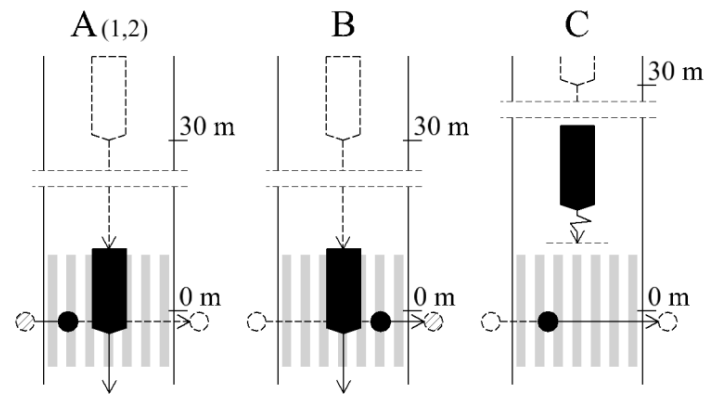

Fig. 3. Sketches of situations analysed

Table 4. Numbers and distribution of events registered

\begin{tabular}{|c|c|c|c|c|c|c|c|}
\hline \multicolumn{2}{|c|}{ SITE } & Number & A1 & A2 & B & C & TOTAL \\
\hline Warsaw POW (both lanes) & without SF & 7088 & $3,9 \%$ & $16,2 \%$ & $15,4 \%$ & $64,5 \%$ & $100,0 \%$ \\
\hline Warsaw POW (both lanes) & with SF & 6418 & $4,6 \%$ & $15,9 \%$ & $14,5 \%$ & $65,0 \%$ & $100,0 \%$ \\
\hline Wrocław CEN & without LL & 1529 & $12,4 \%$ & $42,1 \%$ & $7,9 \%$ & $37,5 \%$ & $100,0 \%$ \\
\hline Wrocław CEN & with LL & 1080 & $12,0 \%$ & $32,6 \%$ & $7,9 \%$ & $47,5 \%$ & $100,0 \%$ \\
\hline
\end{tabular}




\subsection{SPEED PROFILES}

Trajectories and speed profiles of vehicles approaching the zebra crossing were extracted from the video data. Statistical analysis of speed measured at different distances from the crossing was performed for the Warsaw and Wrocław sites. Speed profiles were compared for situations before and after installation of systems which were intended to increase pedestrian safety.

All the pedestrian crossings analysed are located in the built up areas where speed limit is $50 \mathrm{~km} / \mathrm{h}(60 \mathrm{~km} / \mathrm{h}$ at night - between $11 \mathrm{pm}$ and $5 \mathrm{am})$ [9]. Vehicle speed profiles were registered over the distance of thirty metres, measured from the centre of the zebra crossing. Examples of speed profiles corresponding to situation A1 for one day without the SignFlash system are shown in Fig. 4. In the figure, the average speed profile and the band of average \pm standard deviation (SD) are also presented. It can be noted that at the distance of $20 \mathrm{~m}$ about half of the drivers exceeded the speed limit.

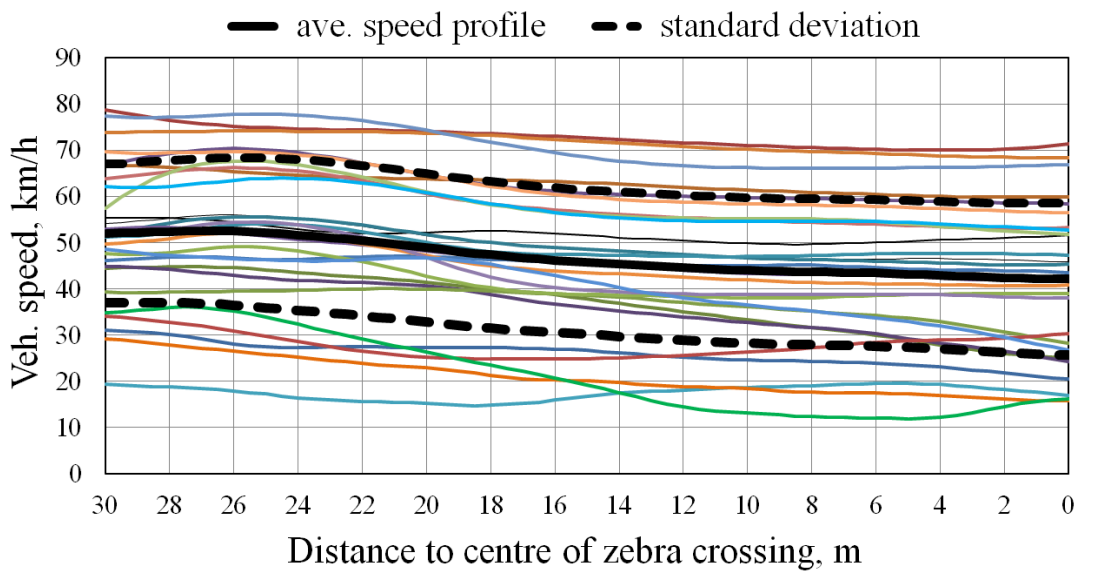

Fig. 4. Vehicle speed profiles for situation A1 (one day 13.11.2013 - without SF)

\subsection{EFFECT OF SignFLASH}

For the selected days in Warsaw (see Section 2) speed profiles of vehicles approaching the zebra crossing in the POW direction and encountering pedestrians were analysed. Figures 5 and 6 show the average speed profiles as well as the speed standard deviation of vehicles for situations A1 and C, with and without the SignFlash (SF) system. The graphs were divided into daytime and night-time periods. 

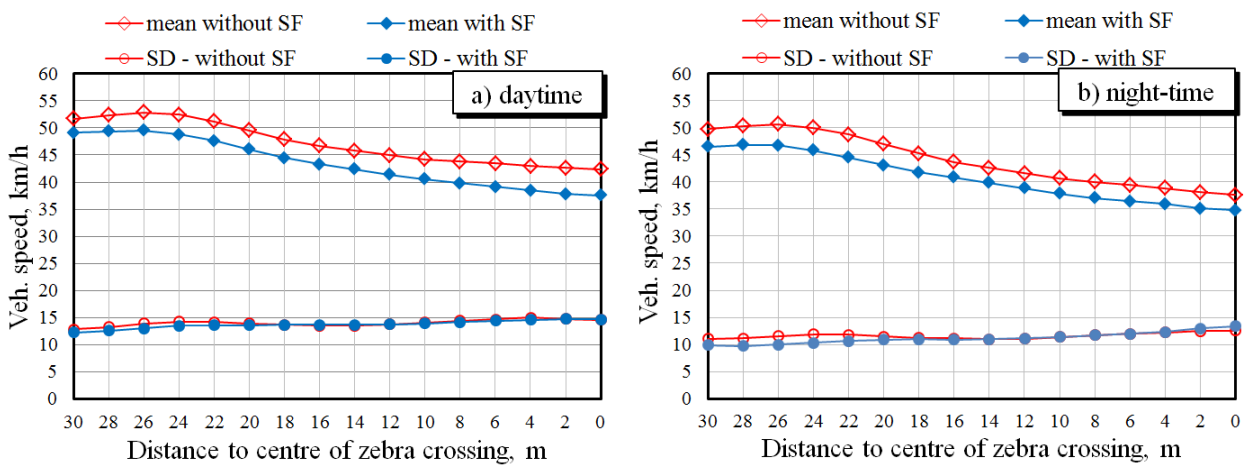

Fig. 5. Averaged speed profiles for situation A1: a) daytime b) night-time -Warsaw POW site
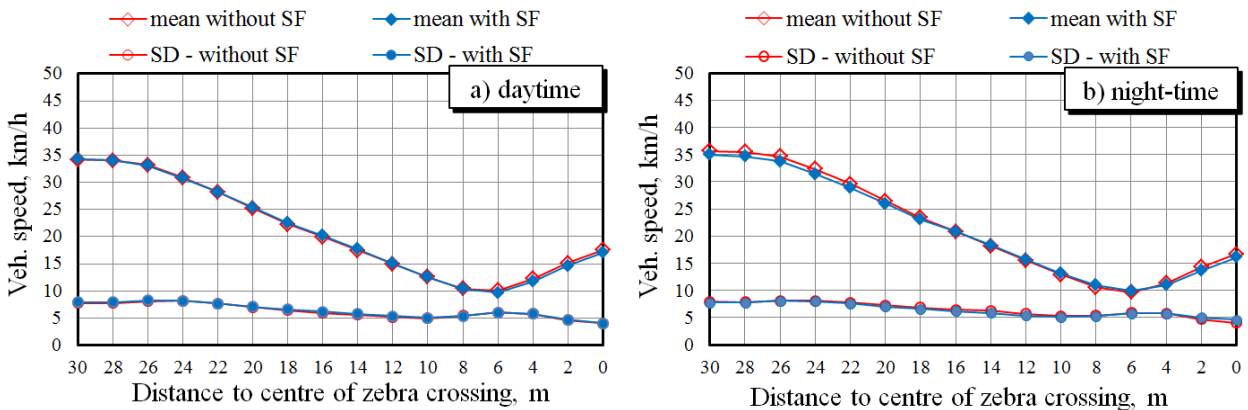

Fig. 6. Averaged speed profiles for situation C: a) daytime b) night-time -Warsaw POW site

The average speed profile shows that the SignFlash system has a positive influence on drivers in situation A1 (see Fig. 5), but there are no benefits in situation $\mathrm{C}$ (see Fig. 6). Comparison of mean vehicle speeds and standard deviations for situations A1 and C is shown in Table 5 . The speeds shown were captured at the distance of $10 \mathrm{~m}$ before the edge of the crossing.

Table 5. Mean and standard deviation of vehicle speed at $10 \mathrm{~m}$ before the edge of zebra - Warsaw POW site

\begin{tabular}{|c|c|c|c|c|c|c|c|c|}
\hline & \multirow{2}{*}{ Situation } & \multicolumn{3}{|c|}{ Without SF } & \multicolumn{3}{|c|}{ With SF } & \multirow{2}{*}{$\begin{array}{c}\text { Difference } \\
\text { in mean } \\
{[\mathrm{km} \backslash \mathrm{h}]}\end{array}$} \\
\hline & & number & $\begin{array}{c}\text { mean } \\
{[\mathrm{km} \backslash \mathrm{h}]}\end{array}$ & $\mathrm{SD}[\mathrm{km} \backslash \mathrm{h}]$ & number & $\begin{array}{c}\text { mean } \\
{[\mathrm{km} \backslash \mathrm{h}]}\end{array}$ & $\begin{array}{c}\mathrm{SD} \\
{[\mathrm{km} \backslash \mathrm{h}]}\end{array}$ & \\
\hline \multirow{2}{*}{ A1 } & a) daytime & 197 & 44.9 & 13.8 & 237 & 41.4 & 13.8 & -3.5 \\
\hline & b) night-time & 81 & 41.6 & 11.1 & 50 & 38.8 & 11.2 & -2.7 \\
\hline \multirow{2}{*}{$\mathrm{C}$} & a) daytime & 2647 & 15.0 & 5.2 & 3242 & 15.1 & 5.3 & -0.1 \\
\hline & b) night-time & 1909 & 15.5 & 5.7 & 917 & 15.7 & 5.4 & -0.2 \\
\hline
\end{tabular}




\subsection{EFFECT OF LEVELITE}

For the selected days in Wrocław (see Section 2) speed profiles of vehicles approaching the zebra crossing in the CEN direction and encountering pedestrians were analysed. Figures 7 and 8 show average speed profiles as well as the speed standard deviation of vehicles for situation A1 and C, with and without the Levelite (LL) system. The graphs were divided into daytime and night-time periods.
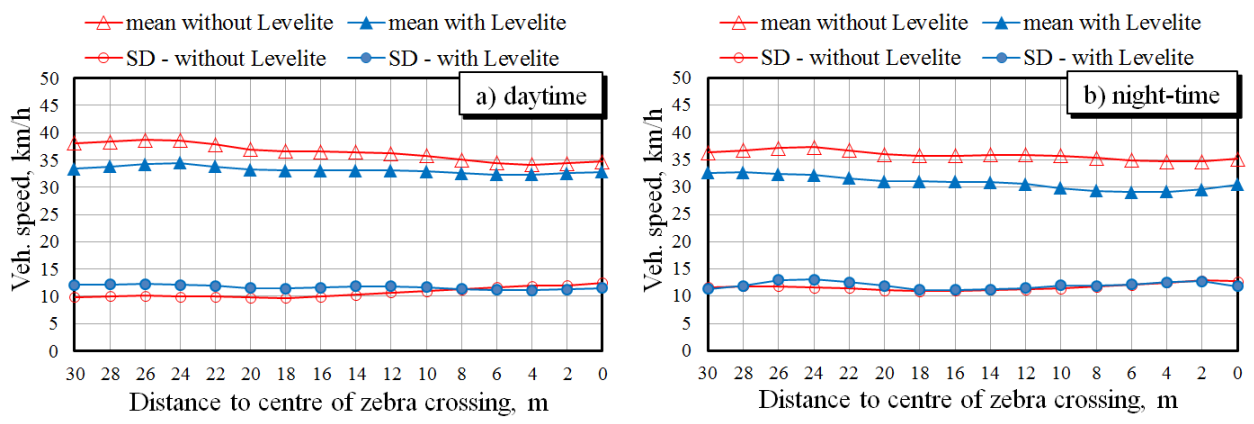

Fig. 7. Averaged speed profiles for situation A1: a) daytime b) night-time -Wrocław CEN site
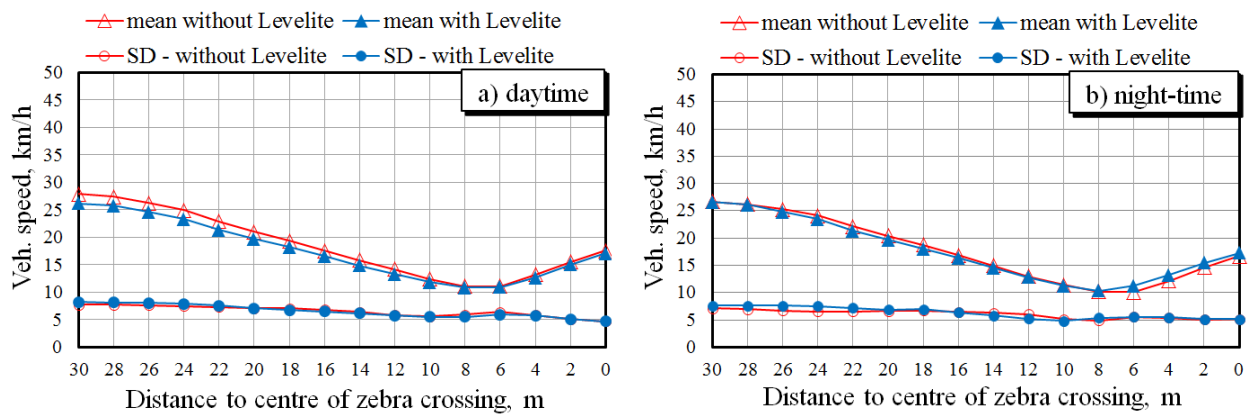

Fig. 8. Averaged speed profiles for situation C: a) daytime b) night-time - Wrocław CEN site

The average speed profile shows that the Levelite system has a positive influence on drivers in situation A1 (see Fig. 7), but there are no benefits in terms of speed reduction in situation C (see Fig. 8). However, in these situations drivers give way to pedestrians anyway and the percentage of such desirable events is clearly higher with LL (see Table 4). Comparison of mean vehicle speed and standard deviation for situations $\mathrm{A} 1$ and $\mathrm{C}$ is shown in Table 6. 
Table 6. Mean and standard deviation of vehicle speed at $10 \mathrm{~m}$ before the edge of zebra - Wrocław CEN site

\begin{tabular}{|c|c|c|c|c|c|c|c|c|}
\hline & & \multicolumn{3}{|c|}{ WITHOUT LL } & \multicolumn{3}{|c|}{ WITH LL } & \multirow{2}{*}{$\begin{array}{c}\text { DIFFERENCE } \\
\text { IN MEAN } \\
{[\mathrm{km} / \mathrm{h}]}\end{array}$} \\
\hline \multicolumn{2}{|c|}{ SITUATION } & number & $\begin{array}{c}\text { mean } \\
{[\mathrm{km} / \mathrm{h}]}\end{array}$ & $\mathrm{SD}[\mathrm{km} / \mathrm{h}]$ & number & $\begin{array}{c}\text { mean } \\
{[\mathrm{km} / \mathrm{h}]}\end{array}$ & $\mathrm{SD}[\mathrm{km} / \mathrm{h}]$ & \\
\hline \multirow{2}{*}{$\mathrm{A} 1$} & a) daytime & 152 & 36.4 & 10.5 & 97 & 33.1 & 11.9 & -3.3 \\
\hline & b) night-time & 38 & 36.0 & 11.2 & 33 & 30.8 & 11.4 & -5.2 \\
\hline \multirow{2}{*}{$\mathrm{C}$} & a) daytime & 479 & 15.0 & 6.1 & 397 & 14.1 & 5.9 & -0.9 \\
\hline & b) night-time & 75 & 13.9 & 6.3 & 115 & 13.7 & 5.5 & -0.2 \\
\hline
\end{tabular}

\section{CONCLUSIONS}

High speed of vehicles approaching a zebra crossing is the main risk factor for pedestrians using the crossing. Therefore, effectiveness of measures aimed at improving pedestrian safety can be assessed by comparing the speed of traffic before and after the measures are introduced. In this respect, both systems of active signage tested show statistically significant improvements.

The SignFlash system of pedestrian-activated yellow flashing beacons installed at the site in Warsaw caused a decrease of the overall average spot speed of approaching vehicles by around $2.5 \mathrm{~km} / \mathrm{h}$.

The decrease is even higher when encounters with pedestrians are considered - for example, the speed reduction is $3.5 \mathrm{~km} / \mathrm{h}$ during the day and $2.7 \mathrm{~km} / \mathrm{h}$ at night for A1 type encounters.

The Levelite system of flashing lights embedded in the pavement which was tested in Wrockaw resulted in the average spot speed decrease of $5.4 \mathrm{~km} / \mathrm{h}$ for continuous flashing and $1.9 \mathrm{~km} / \mathrm{h}$ for pedestrian-activated flashing, measured for all vehicles.

The effect is also clearly visible on speed profiles of vehicles approaching the crossing when pedestrians are waiting to cross: $3.3 \mathrm{~km} / \mathrm{h}$ reduction during the day and $5.2 \mathrm{~km} / \mathrm{h}$ reduction at night. 


\section{REFERENCES}

1. Wypadki drogowe - raporty roczne (Road accidents - yearly reports), webpage: http://statystyka.policja.pl/st/ruch-drogowy/76562,Wypadki-drogowe-raporty-roczne.html

2. P. Olszewski et al., Badanie zachowań uczestników ruchu na przejściach dla pieszych na podstawie analizy obrazu, Budownictwo i Architektura, Vol. 13, No. 4, pp. 177-184, 2014.

3. P. Szagała et al., Safety assessment of pedestrian crossings with video analysis, 27th ICTCT Workshop, Karlsruhe, Germany, 16-17 October 2014.

4. W. Czajewski, P. Dąbkowski, P. Olszewski, Innovative solutions for improving safety at pedestrian crossings. Archives of Transport System Telematics, Vol. 6 No. 2, pp. 16-22, 2013.

5. R. A. Retting, S. A. Ferguson, A. T. McCartt, A review of evidence-based traffic engineering measures designed to reduce pedestrian-motor vehicle crashes. American Journal of Public Health, Vol. 93, No. 9, 14561463, 2003.

6. P. D. Prevedouros, Evaluation of in-pavement flashing lights on a six-lane arterial pedestrian crossing. In: ITE 2001 Annual Meeting, ITE, 2001.

7. S. Turner, K. Fitzpatrick, M. Brewer, E. S. Park, Motorist yielding to pedestrians at unsignalized intersections: Findings from a national study on improving pedestrian safety. Transportation Research Record: Journal of the Transportation Research Board, No. 1982, pp. 1-12, 2006.

8. A. S. Hakkert, V. Gitelman, E. Ben-Shabat, An evaluation of crosswalk warning systems: effects on pedestrian and vehicle behaviour. Transportation Research Part F: Traffic Psychology and Behaviour, Vol. 5.4, pp. 275$292,2002$.

9. Dziennik Ustaw nr 98 poz. 602 z dnia 20 czerwca 1997 r. - Prawo o ruchu drogowym (The Highway Code).

\section{LIST OF FIGURES AND TABLES:}

Fig. 1. Layout of the two test sites in Warsaw (a) and Wrocław (b)

Rys. 1. Schematy poligonów badawczych: (a) Warszawa oraz (b) Wrocław

Fig. 2. Regression analysis for the Wrocław CEN site

Rys. 2. Analiza regresji dla kierunku CEN we Wrocławiu

Fig. 3. Sketches of situations analysed

Rys. 3. Schematy analizowanych sytuacji

Fig. 4. Vehicle speed profiles for situation A1 (one day 13.11.2013 - without SF)

Rys. 4. Profile prędkości pojazdów dla sytuacji A1 (jeden dzień 13.11.2013 - bez SF)

Fig. 5. Averaged speed profiles for situation A1: a) daytime b) night-time-Warsaw POW site Rys. 5. Uśrednione profile prędkości dla sytuacji A1: a) dzień b) noc - Warszawa kierunek POW

Fig. 6. Averaged speed profiles for situation C: a) daytime b) night-time -Warsaw POW site Rys. 6. Uśrednione profile prędkości dla sytuacji C: a) dzień b) noc - Warszawa kierunek POW

Fig. 7. Averaged speed profiles for situation A1: a) daytime b) night-time -Wrocław CEN site Rys. 7. Uśrednione profile prędkości dla sytuacji A1: a) dzień b) noc - Wrocław kierunek POW

Fig. 8. Averaged speed profiles for situation C: a) daytime b) night-time - Wrocław CEN site Rys. 8. Uśrednione profile prędkości dla sytuacji C: a) dzień b) noc - Wrocław kierunek POW

Tab. 1. Spot speed analysis for the three sites

Tab. 1. Analiza prędkości chwilowej dla trzech poligonów 
Tab. 2. Regression analysis results, Warsaw POW site

Tab. 2. Wyniki analizy regresji, Warszawa kierunek POW

Tab. 3. Regression analysis results, Wrocław site

Tab. 3. Wyniki analizy regresji, Wrocław

Tab. 4. Numbers and distribution of events registered

Tab. 4. Liczby i rozkład zarejestrowanych zdarzeń

Tab. 5. Mean and standard deviation of vehicle speed at $10 \mathrm{~m}$ before the edge of zebra - Warsaw site

Tab. 5. Średnia i odchylenie standardowe prędkości mierzonej $10 \mathrm{~m}$ przed początkiem przejścia - Warszawa

Tab. 6. Mean and standard deviation of vehicle speed at $10 \mathrm{~m}$ before the edge of zebra - Wrocław site

Tab. 6. Średnia i odchylenie standardowe prędkości mierzonej $10 \mathrm{~m}$ przed początkiem przejścia - Wrocław 


\section{OCENA SKUTECZNOŚCI OZNAKOWANIA AKTYWNEGO NA PRZEJŚCIACH DLA PIESZYCH}

Slowa kluczowe: Bezpieczeństwo pieszych, przejście dla pieszych, badania prędkości, SignFlash, Levelite

\section{STRESZCZENIE:}

Celem referatu jest przedstawienie wyników oceny skuteczności zastosowania aktywnego oznakowania na przejściach dla pieszych. Artykuł prezentuje częściowe rezultaty projektu MOBIS (finansowanego przez Narodowe Centrum Badań i Rozwoju), który ma na celu opracowanie metody oceny bezpieczeństwa ruchu na przejściach dla pieszych bez sygnalizacji przy pomocy analizy obrazu wideo. Na wybranych przejściach dla pieszych w Warszawie i we Wrocławiu ruch pieszych i pojazdów był rejestrowany przed i po instalacji oznakowania aktywnego SignFlash i Levelite, które to systemy sygnalizują obecność pieszych na przejściu.

Przy pomocy analizy obrazu dokonano pomiarów prędkości pojazdów zbliżających się do przejścia oraz klasyfikacji zachowań kierowców pojazdów. Sklasyfikowano 4 rodzaje możliwych sytuacji: pojazd przejeżdża tuż przed pieszym, który jest w tym momencie na przejściu dla pieszych (A1); pojazd przejeżdża przed pieszym, który jest w tym momencie na chodniku (A2); pojazd przejeżdża tuż za pieszym; który jest w tym momencie na przejściu dla pieszych (B); kierowca widząc pieszego zwalnia lub zatrzymuje się przed przejściem (C).

Referat przedstawia porównanie efektywności systemów SignFlash i Levelite na podstawie zmian średnich oraz wariancji prędkości pojazdów przed przejściem. W ramach projektu dokonano też analizy zmian profili prędkości pojazdów zbliżających się do przejścia dla sytuacji A1 oraz C. Analiza profili prędkości została wykonana osobno dla pory dziennej i nocnej, czyli okresów kiedy występuje i nie występuje naturalne oświetlenie słoneczne.

Uśrednione profile prędkości na odcinku 30 metrów od środka przejścia dla pieszych pokazały - zarówno dla poligonów badawczych w Warszawie jak i we Wrocławiu - że wpływ systemów oznakowania aktywnego na zachowania kierowców jest większy w nocy, kiedy systemy te są zdecydowanie bardziej widoczne od tradycyjnie stosowanych rozwiązań.

System SignFlash, aktywujący żółte migające światło w momencie pojawienia się pieszego bezpośrednio przed przejściem, został zainstalowany w Warszawie i spowodował obniżenie średnich prędkości o $2,5 \mathrm{~km} / \mathrm{h}$. Stopień obniżenia średnich prędkości jest jeszcze wyższy - 3,5 km/h w ciągu dnia i $2,7 \mathrm{~km} / \mathrm{h}$ w nocy - w przypadku sytuacji A1. System Levelite składający się z migających światełek wbudowanych w konstrukcję nawierzchni drogowej był badany na poligonie we Wrocławiu. Jego działanie spowodowało zmniejszenie średnich prędkości o 5,4 km/h w przypadku świecenia ciągłego i $1,9 \mathrm{~km} / \mathrm{h}$ przy świeceniu aktywowanym przez pieszego wchodzącego na przejście. Efekt ten jest szczególnie widoczny na uśrednionych profilach prędkości pojazdów zbliżających się do przejścia w sytuacjach A1 - redukcja w ciągu dnia o $3,3 \mathrm{~km} / \mathrm{h}$ i w nocy o $5,2 \mathrm{~km} / \mathrm{h}$.

Wyniki badań potwierdzają skuteczność zastosowania aktywnego oznakowania na przejściach dla pieszych. Obydwa rozwiązania (SignFlash i Levelite) powodują zmniejszenie średnich prędkości pojazdów i mają pozytywny wpływ na zachowania kierowców. 
